Jurnal Interpretasi Hukum | ISSN: 2746-5047

Vol. 2, No. 3-Desember 2021, Hal. 520-524| Tersedia online di

https://www.ejournal.warmadewa.ac.id/index.php/juinhum

DOI: https://doi.org/10.22225/juinhum.2.3.4130.520-524

\title{
AKIBAT HUKUM TERHADAP PENGURUSAN BIAYA NAFKAH DAN PENDIDIKAN ANAK PASCA PERCERAIAN
}

\author{
I Putu Yoga Febrian Cahya, I Nyoman Putu Budiartha, Ni Komang Arini Styawati \\ Fakultas Hukum, Universitas Warmadewa, Denpasar-Bali, Indonesia \\ yogafebriany@yahoo.co.id, budiarthaputu59@gmail.com, arinistyawati@gmail.com
}

\begin{abstract}
Abstrak
Pertanggung jawaban terhadap orangtua kepada anaknya adalah sebuah berkewajiban yang seharusnya dijalankan oleh setiap orang tuanya. Anak memperoleh hak semua pentingnya guna mendukung tumbuh berkembangnya dan berhak memperoleh hak asuh dari orang tuanya dengan sebaik-baiknya. Berakhirnya perkawinan antara istri dan suami tidak menghapuskan semua kewajiban orangtuanya kepada anaknya. Tujuan penelitian ini untuk mengetahui pertanggung jawaban orang tua terhadap anak pasca perceraian orangtuanya serta akibat hukum terhadap orang tua yang tidak melaksanakan kewajibannya. Penelitian ini menggunakan tipe penelitian normatif dengan pendekatan perundang-undangan serta pendekatan konseptual. Teknik pengumpulan bahan hukum dilakukan dengan menerapkan studi kepustakaan. Sumber bahan hukum berupa bahan hukum primer, sekunder, dan tersier yang kemudian dianalisis menggunakan metode pengolahan bahan hukum secara sistematis dan hasilnya disajikan secara deskriptif. Hasil penelitian menunjukkan bahwa pengurusan biaya nafkah anak dapat dilihat dari Kitab Undang-undang Hukum Perdata, Undang-undang Tahun 2019 Tentang Perkawinan, Undang-undang Nomor 35 Tahun 2014, Undang-undang Nomor 4 Tahun 1979 Tentang Kesejahteraan. Adapun akibat hukum untuk kedua orang tua yang tidak menjalankan kewajibannya bisa dilakukan dengan 2 (dua) cara yakni Permohonan Eksekusi serta Pencabutan Hak asuh ke Pengadilan Agama.
\end{abstract}

Kata Kunci: Akibat Hukum, Tanggung Jawab, Perceraian

\begin{abstract}
Responsibility for parents to their children is an obligation that should be carried out by every parent. Children get all the important rights to support their growth and development and are entitled to the best possible custody of their parents. The end of the marriage between the wife and husband does not abolish all the obligations ofparents to their children. The purposes of this study are to determine the responsibility ofparents to children after their parents' divorce and the legal consequences for parents who do not carry out their obligations. This research uses a normative research type with a statutory approach and a conceptual approach. The technique of collecting legal materials is done by applying a literature study. Sou rces oflegal materials in the form of primary, secondary, and tertiary legal materials which are then analyzed using the method of processing legal materials systematically and the results are presented descriptively. The results of the study indicate that the management of child support costs can be seen from the Civil Code, the 2019 Law on Marriage, Law Number 35 of 2014, Law Number 4 of 1979 concerning Welfare. The legal consequences for both parents who do not carry out their obligations can be done in 2 (two) ways, namely Application for Execution and Revocation of Custody to the Religious Court.
\end{abstract}

Keywords: Legal Consequences, Responsibility, Divorce

\section{PENDAHULUAN}

Perkawinan berdasarkan Pasal (1) UU Nomor 1 Tahun 1974 yang sudah diubah menjadi UU Nomor 16 Tahun 2019 Tentang Perkawinan (kemudian disebut UU Perkawinan) yakni ikatan batin diantara pria dan wanita selaki suami isteri dengan maksud mewujudkan rumahtangga yang bahagia serta kekal berlandaskan Ketuhanan Yang Maha Esa. Ikatan batin artinya para pihak tersebut sebab perkawinan yang formal adalah suami istri baik untuk mereka pada hubungan satu sama lain ataupun untuk mereka terhadap masyarakat luas. Definisi ikatan lahir batin pada perkawinan artinya dalam bathin suami istri tersebut terdapat niat yang sungguh sungguh guna hidup Bersama selaku suami istri dengan maksud mewujudkan serta membina keluarga bahagia yang kekal, jelasnya pada sebuah perkawinan tidak di perkenankan sekedar ikatan lahir batin atau ikatan batin saja semua unsur itu terdapat pada setiap perkawinan. Tujuan dari terdapatnya ikatan supaya pasangan suami serta istri 
bisa mempunyai keturunan, untuk menjaga generasi penerusnya (Atmadja, I Dewa Gede Budiartha, 2018).

Keberadaan anak kepada keluarga adalah kebahagiaan atas sebuah perkawinan. Sebab pada dasarnya anak adalah anugerah dari Tuhan Yang Maha Esa yang diberikan terhadap manusia atau pria dan wanita yang telah menikah yang wajib dijaga, dirawat serta mendidik sebaik-baiknya, agar anak bisa tumbuh kembang secara baik dan nantinya bisa bermanfaat untuk nusa, bangsa, agama maupun keluarga. Pada hakikatnya anak tidak bisa melindungi dirinya akan sejumlah tindakan memicu terganggu mental, fisik dan sosial pada sejumlah dalam bidang kehidupan dirinya kedepan, mempertimbangkan situasi serta kondisinya. Anak membutuhkan perhatian dan perlindungan supaya tidak merasakan kerugian, naik mental, fisik dan sosial. Anak pun memiliki hak akan pelayanan guna mengemabangkan keterampilan serta kehidupan sosial. Anak pun berhak akan perlindungan dari lingkungan hidup yang membahayakan serta mengganggu pertumbuhannya secara wajar. Maka dari itu orangtua harus memberi tanggung jawab untuk semua pemeliharaan hak yang dimiliki anak-anak. Anak musti dijaga supaya anak tidak jadi korban perbuatan siapapun (perorangan atau organisasi atau kelompok, organisasi wanita) bertindak dengan langsung maupun tidak langsung. Walaupun kedua orang tua anak sudah bercerai atau berpisah, namun kewajiban selaku orang tua guna memberikan haknya terhadap keturunannya belumlah selesai. Anak musti tetap memperoleh haknya selaku anak. Dalam hal ini, kewajiban seorang ayah terhadap nafkah anak secara jelas sudah diatur dalam INPRES Nomor 1 tahun 1991 yang lebih dikenal degan Kompilasi Hukum Islam (KHI) yakni seorang mantan suami atau ayah berkewajiban memberikan biaya pemeliharaaan untuk anak-anaknya sampai anak mencapai umur 21 tahun atau sudah dewasa (Lubis et al., 2021).

Tetapi sangat disayangkan dari tidak sedikit hak yang dimiliki anak yang belum cukup terjamin tentang hak anak pasca perceraian atau hak yang sudah bercerai dengan ayah maupun ibunya. Berakhirnya perkawinan antara suami terhadap istri sebab tidak ada kerukunan pada hubungan rumah tangga atau alasan lain misalnya tidak subur atau mandulnya isteri atau suami serta usai sebelum diusahakan berdamai dengan mengikut sertakan keluarga kedua belah pihak. Perceraian baru bisa dilakukan jika sudah ditempuh sejumlah cara guna berdamai dengan kedua belah pihak melanjutkan keutuhan rumah tangga yang harmonis serta nyatanya tidak terdapat solusi lain diluar perceraian. Dengan istilah lain jika perceraian tersebut merupakan selaku way out untuk suami istri guna kebahagian yang bisa didapat pasca perceraian dilakukan (Faradz, 2008).

Ditegaskan jika perceraian hanya dapat dijalankan pada sidang pengadilan, pasca pengadilan bersangkutan gagal mendamaikan para pihak. Ditentukan pula jika guna melakukan perceraian mesti terdapat cukup alasan, yakni jika di antara suami istri tersebut tidak bisa hidup damai selaku suami istri. Akibat perceraian kadang kala hak-hak anak ada yang dilupakan, khususnya yang berhubungan terhadap hak-hak pokok anak yakni biaya pemeliharaan, pendidikan, rumah serta sarana pendukung yang lain. Apalagi saat orang tuanya telah mempunyai keluarga baru alhasil dimungkinkan berkurang nya waktu guna mencukupi hak-hak anaknya. Walaupun orang tua telah tidak kembali pada satu keluarga namun permasalahan hak-hak selalu jadi tanggung jawab orang tua serta dilarang diberikan terhadap orang lain diluar kedua orang tuanya.

Adapun penelitian sebelumnya dari Sipahutar et al., (2016) mengungkapkan bahwa tanggung jawab orang tua yang telah bercerai terhadap anak (hadhanah) bagi WNI yang beragama Islam, dapat merujuk pada Undang-undang No. 1 Tahun 1974 tentang perkawinan dalam Pasal 41 huruf (b), akibat hukumnya dengan tegas menyatakan bahwa semua biaya hadhanah dan nafkah anak menjadi tanggung jawab ayah dapat dilihat dalam Pasal 105 KHI menurut kemampuannya, sekurangkurangnya sampai anak tersebut dewasa/dapat mengurus dirinya sendiri, dasar yuridisnya Pasal 98 ayat (1) KHI. Sedangkan menurut Mumu (2018) menjelaskan bahwa akibat hukum bagi orang tua yang tidak melaksanakan tanggung jawab terhadap anak dalam UU No. 11974 Pasal 45 ayat (1) terdapat dua akibat yaitu permohonan eksekusi dan pencabutan hak asuh. Lebih lanjut, menurut hukum positif di Indonesia bahwa sanksi hukum bagi seorang ayah yang melalaikan kewajiban nafkah kepada anak dapat dikenakan sanksi perdata maupun pidana (Andini, 2019). Dari kasus tersebut, maka dilakukannya penelitian yang bertujuan untuk mengetahui pertanggungjawaban orang tua terhadap anak pasca perceraian orangtuanya serta akibat hukum terhadap orang tua yang tidak melaksanakan kewajibannya. 


\section{METODE PENELITIAN}

Metode Penelitian yang dipakai terhadap penelitian ini yaitu penelitian hukum normatif, pendekatan masalah melalui perundang-undangan, serta pendekatan konseptual. Teknik Pengumpulan Bahan Hukum untuk penelitian ini, penulis mengumpulkan bahan-bahan Hukum dengan cara yaitu Studi Kepustakaan yaitu Teknik pengumpulan Bahan Hukum melalui cara dengan mengumpulkan sejumlah jenis bahan bacaan yakni buku-buku literatur, ketentuan undang-undang, artikel-artikel hukum, serta bacaan-bacaan yang lain. Ada beberapa sumber hukum dari bahan hukum primer yang mencakup KUHPerdata, UU Nomor 16 Tahun 2019 mengenai Perkawinan, UU Nomor 35 Tahun 2014 Perlindungan Anak, serta Undang-undang Nomor 4 Tahun 1979 mengenai Kesejahteraan. bahan hukum sekunder yang dikutip dari kajian kepustakaan yang meliputi membaca beberapa buku, jurnaljurnal hukum, serta artikel yang berhubungan mengenai pengurusan biaya nafkah anak setelah perceraian, adapun bahan hukum Tersier yakni bahan hukum yang berupa KBBI maupun Kamus Bahasa Latin serta Bahasa Inggris. Setelah bahan hukum telah terkumpul, maka bahan hukum tersebut akan akan diolah dan dianalisis menggunakan metode pengolahan bahan hukum secara sistematis. Dan hasilnya disajikan secara deskriptif (Cholifah \& Kusumo, 2011).

\section{HASIL DAN PEMBAHASAN}

\section{Pertanggungjawaban Orang Tua Terhadap Anak Pasca Perceraian}

Pada KBBI hak mempunyai definisi mengenai sesuatu hal yang benar, milik, kepunyaan, kewenangan, kekuasaan guna berbuat sesuatu (sebab sudah ditetapkan UU, aturan, dan lainnya), kekuasaan yang benar dari sesuatu atau guna meminta sesuatu, derajat atau martabat. Kewajiban tersebut berasal dari kata wajib, memperoleh awalan ke- serta akhiran -an, yang artinya seluruh hal yang mesti dicukupi. Jika dikatakan kewajiban orang tua artinya hak-hak yang terdapat di anak serta kewajiban orang tua kepada anaknya yang wajib dicukupinya. Kewajiban merupakan sebuah beban atau tanggungan yang sifatnya kontraktual. Istilah lainnya kewajiban merupakan suatu hal yang selayaknya diberikan. Senada terhadap adanya hak serta kewajiban itu, maka muncul juga keadilan, yakni pengakuan serta tindakan kepada hak yang sah. Mempertimbangkan hubungan hak serta kewajiban begitu kuat, maka dimana terdapat hak, maka terdapat kewajiban serta dimana terdapat kewajiban maka terdapat hak, yakni menjalankan serta melakukan hak disesuaikan terhadap tempat, waktu serta bobot yangseimbang. Dengan terlaksananya hak serta kewajiban, maka dengan otomatis bisa menunjang terwujudnya tindakan yang akhlaqi. Disinilah posisi hubungan fungsional antara hak, kewajiban serta keadilan terhadap akhlak (Ahmadi, 2008).

Anak merupakan generasi penerus mendatang. Baik buruknya masa depan negara ditentukan juga dari baik buruknya keadaan anak sekarang. Berhubungan terhadap hal itu, maka perlakuan kepada anak dengan cara yang baik merupakan kewajiban kita bersama, supaya anak dapat tumbuh berkembang secara baik serta bisa jadi pengemban risalah peradaban negara ini. Berhubungan terhadap perlakuan kepada anak itu, maka penting untuk kita memahami hak-hak serta kewajiban anak. Pertanggungjawaban orang tua terhadap anaknya adalah sebuah kewajiban yang mesti dijalankan oleh seluruh orangtuanya. Anak wajib yang guna memperoleh semua kepentingan untuk mendukung perkembangannya dengan wajar, anak berhak mendapat kepentingan mendapat sandang,papan dan pangan wajar, anak berhak guna memperoleh Pendidikan dan bimbingan yang wajar dan wajib guna memperoleh didikan orang tuanya dengan sebaik-baiknya. Bahwa putusnya perkawinan terhadap isteri dan suami tidaklah menghapuskan kewajiban semua orangtua kepada anaknya, maksudnya semua hak-hak yang dimiliki anak sedikitpun tidak diperkenankan atau akibat suatu perceraian. Orang tua selalu berkewajiban guna membesarkan atau mendidik anak secara sebaik-baiknya walaupun orang tuanya bercercerai atau berpisah (Hadikusumah, 1992). Pertanggung jawaban untuk mensejahterakan anak jadi kewajiban mendidik serta memelihara anak sebaik mungkin, alhasil anak bisa tumbuh serta berkembang jadi orang yang cerdas,sehat dan berbakti terhadap orang tua dan mempunyai budi pekerti luhur. Mendidik anak pun memiliki arti yang suatu kewajiban orangtua guna mengawasi, memberikan perhatian yang semestinya dan mencukupi keperluan tumbuh kembang hidup anak dari orangtuanya.

Pada Undang-undang Perkawinan menetapkan kewajiban orang tua terhadap anak-anaknya walaupun rumah tangga sudah putus sebab perceraian. Kewajiban tersebut yakni

1. Orang tua wajib memelihara serta mendidik anak mereka sebaik baiknya. 
2. Orang tua mewakili anak tentang tindakan hukum di dalam serta di luar pengadilan.

3. Seperti diatur dalam Pasal 41 UU Perkawinan ditegaskan bapak bertanggung jawab untuk seluruh biaya pemeliharaan serta pendidikan yang dibutuhkan anak, jika bapak tidak mampu mencukupi kewajibannya, pengadilan bisa menetapkan jika ibu juga menanggung biaya pemeliharaannya serta pendidikan yang dibutuhkan anak, kewajiban itu tetap berjalan walaupun kekuasaan selaku orang tua dicabut.

Tanggung jawab orang tua terhadap anak pun ditegaskan pada Pasal 26 Nomor 35 Tahun 2014. Amandemen untuk UU Nomor 23 Tahun 2002 mengenai Perlindungan Anak, yakni

1. Orang tua berkewajiban serta bertanggung jawab guna mengasuh, memelihara, mendidik, serta menjaga anak, menumbuh kembangkan anak berdasarkan kemampuan, bakat, serta minatnya, serta menghindari munculnya perkawinan pada usia dini.

2. Bilamana orang tua tidak ada, atau tidak diketahui keberadaannya atau sebab sebuah alasan, tidak bisa menjalankan kewajiban serta tanggung jawabnya, kemudian kewajiban serta tanggung jawab seperti ditentukan pada ayat (1) bisa berpindah terhadap keluarga, yang dijalankan berdasarkan peraturan undang-undang yang berlaku.

\section{Akibat Hukum Terhadap Orang Tua yang Tidak Melaksanakan Kewajibannya}

Hal yang wajib dijaga pasca timbul perceraian di antara kedua orang tua yakni kesadaran guna selalu menjaga serta tidak menurunkan sedikitpun hak-hak yang selayaknya musti dikasih terhadap anak. Akibat anak-anak yang telah menjadi korban perceraian yakni dengan tidak lagi tinggal kembali dengan orang tuanya, dimana anak itu dengan sendirinya akan bersama dengan salah satu orangtuanya. Dampaknya banyaknya kelalaian kepada kewajiban yang selayaknya mesti dijalankan oleh salah satu orangtua yang telah bercerai agar memberikan sesuatu yang layaknya perhatian untuk mendukung perkembangan anak dengan baik (Ihwanudin, 2016).

Akibat hukum yang diberikan orangtua yang tidak melaksanakan kewajibanya, yakni pada aspek pertama jika ayahnya dari anak tersebut itu tidak menjalankan kewajiban serta kedua jika si ibu anak itu pun tidak menjalankan kewajiban selaku pemegangan hak asuh atau tinggal Bersama dengan anaknya.Dampak kelalaian orang tuanya untuk menjalankan kewajibannya selaku orangtua terhadap anak pasca perceraian maka bisa ditempuh atau bisa diusahakan hal-hal dibawah ini

1. Permohonan Eksekusi

Mempertimbangkan jika putusan dari pengadilan tersebut memiliki kekuatan yang mengikat, putusan dari pengadilan pun memiliki kekuatan eksekutorial. Yakni memiliki kekuatan yang mana putusan dari pengadilan itu bisa mengajukan permohonan guna untuk mengeksekusi menggunakan alat negara jika pihak yang sudah diputuskan dari pengadilan guna menjalankan sebuah berkewajiban yang mesti dijalankan serta jika pihak yang idealnya menjalankan kewajiban itu tidak menjalankan secara sukarela berdasarkan putusan pengadilan atau sengaja melupakan guna tidak melaksanakan dari putusan maka bisa diajukan permohonan guna mengeksekusi putusan itu dekan paksa yakni melakukan pengajuan pemohon eksekusi ke Pengadilan Agama setempat.

2. Pencabutan Hak Asuh.

Berlandaskan Pasal 49 Ayat (1) UU No. 16 Tahun 2019 Mengenai perkawinan yang menegaskan jika salah seorang atau kedua orang tua dapat dicabut kekuasaannya terhadap seorang anak atau lebih untuk waktu yang tertentu atas permintaan orang tua yang lain, keluarga anak dalam garis lurus keatas dan saudara kandung yang telah dewasa atau pejabat yang berwenang dengan keputusan pengadilan dalam hal- hal Ia sangat melalaikan kewajiban terhadap anak anaknya Ia berkelakuan buruk sekali. Tetapi, jika kekuasaan orang tua dicabut mereka masih diharuskan untuk melakukan pemeliharaan kepada anak anaknya, hal tersebut berdasarkan Pasal 49 ayat (2) UU No. 16 Tahun 2019 merupakan Perkawinan yang menegaskan Walaupun orangtua dicabut hak kekuasaannya, mereka masih berkewajiban memberikan didkan atau pemeliharaan terhadap anak tersebut. Merujuk pada pemaparan tersebut, akibat hukum untuk orang tua yang tidak menjalankan tanggung jawab kepada anak pada UU No 162019 Pasal 45 ayat (1) ada 2 akibat yakni permohonan eksekusi serta pencabutan hak asuh. 


\section{SIMPULAN DAN SARAN \\ 1. Simpulan}

Tanggung jawab orangtua terhadap anak akibat dari perceraian orangtua berdasarkan UU Perkawinan yaitu, jika kewajiban orang tua kepada anaknya pada hakikatnya terbagi menjadi 2 bagian, yakni pemeliharaan serta pendidikan. Kewajiban ini musti dijalankan hingga anak tersebut kawin atau bisa berdiri sendiri meskipun perkawinan antara orang tua nya sudah berakhir dan untuk biaya pemeliharaan anak, biaya pemeliharaan serta pendidikan anak berdasarkan Pasal 41 ayat (2 UU Nomor.16 Tahun 2019 mengenai Perkawinan menegaskan bahwa bapaklah yang mempunyai tanggung jawab untuk seluruh biaya pemeliharaan serta pendidikan yang dibutuhkan anak itu, tetapi jika bapak terbukti tidak mampu guna menjalankan kewajiban itu maka pihak pengadilan bisa menetapkan jika ibu juga menanggung biaya itu. Adapun akibat hukum untuk orangtua yang tidak menjalankan kewajibannya kepada anak pasca Perceraian menurut Pasal 26 ayat (1) UU 35 Tahun 2014 mengenai perlindungan anak yaitu, maka bisa diusahakan dua hal Pertama, Kepada pihak yang dibebani biaya nafkah, jika tidak menjalankan kewajibannya bisa dimohonkan eksekusi. Kedua, kepada pemegang kuasa asuh, jika tidak menjalankan kewajibannya maka bisa diajukan permintaan pencabutan kuasa asuh. Namun pencabutan kuasa asuh itu tidak membuat kewajiban selaku orang tua terhadap anaknya hapus.

\section{Saran}

Kepada Hakim supaya tambah cermat serta tepat guna menganalisa hukum dan tambah cerdas untuk menginterpretasi hukum, pada situasi yang masih dapat dijalankan pendekatan dengan kekeluargaan supaya implementasi hukum tidak berjalan terlalu kaku serta terlalu formal alhasil terkadang malah membawa hukum jauh dari rasa keadilan. Kepada orang tua hendaknya sebelum memutuskan untuk melakukan perceraian sebaiknya dipikirkan terlebih dahulu dan tambah mendalam kembali dampak yang akan muncul pasca perceraian, akan lebih baik bila orang tua mengalah guna saling bersamasama mengedepankan kepentingan anak. Sebab berakhirnya perkawinan di antara orangtua pasti sedikit banyak bisa mempengaruhi atau berdampak menurunnya pemenuhan hak yang idealnya dilaksanakan kedua orangtua kepada anak.

\section{DAFTAR PUSTAKA}

Ahmadi, W. (2008). Hak dan Kewajiban Keluarga Menurut Undang-undang Nomor 1 Tahun 1974 Tentang Perkawinan. Jurnal Hukum PRO JUSTITIA, 26(4), 371-390.

Andini, N. (2019). Sanksi Hukum Bagi Ayah yang Tidak Melaksanakan Kewajiban Nafkah Terhadap Anak Pasca Perceraian (Studi Komparatif Perspektif Hukum Islam dan Hukum Positif di Indonesia). Jurnal Hukum Islam Dan Peradilan, 4(1), 1-10.

Atmadja, I Dewa Gede Budiartha, I. N. P. (2018). Teori-teori Hukum. Setara Press, Malang.

Cholifah, N., \& Kusumo, B. A. (2011). Hak Nafkah Anak Akibat Perceraian. Wacana Hukum, 9(2), $52-65$.

Faradz, H. (2008). Tujuan dan Manfaat Perjanjian Perkawinan. Jurnal Dinamika Hukum Hukum, 8(3), 249-252.

Hadikusumah, H. (1992). Pengantar Ilmu Hukum Adat Indonesia. Mandar Maju, Bandung.

Ihwanudin, N. (2016). Pemenuhan Kewajiban Pasca Perceraian di Pengadilan Agama. Abliya, 10(1), 51-68.

Lubis, A. M., Angga, L. O., \& Labetubun, M. A. H. (2021). Implementasi Alimentasi Anak Dalam Suatu Perceraian (Studi Kasus Putusan Pengadilan Agama Ambon Nomor: 312/Pdt.G/2018/Pa Ambon. TATOHI, 1(1), 31-40.

Mumu, V. A. J. (2018). Tinjauan Yuridis Tentang Tanggung Jawab Orang Tua Terhadap Anak Setelah Perceraian Dalam UU No 11974 Pasal 45 Ayat (1). Lex Privatum, 6(8), 159-168.

Sipahutar, A., Kamello, T., Runtung, \& Barus, U. M. (2016). Tanggung Jawab Orang Tua Terhadap Nafkah Anak Pasca Putusan Perceraian Bagi Warga Negara Indonesia yang Beragama Islam. USU Law Journal, 4(1), 152-167. 